\title{
CONSTITUCIONALISMO MODERNO: SIMBOLOGIA DAS REVOLUÇÕES LIBERAIS-BURGUESAS
}

\begin{abstract}
Alessandra Malheiros Fava da Silva*1
RESUMO:

O Constitucionalismo Moderno surge a partir do século XVIII como movimento político, social e cultural após período de ruptura com o modelo tradicional de poder político. Os três grandes movimentos político-sociais Inglês, Americano e Francês, conhecidos como Revoluções Liberais-Burguesas, foram responsáveis pela formação do Constitucionalismo Moderno. $\mathrm{O}$ artigo contempla abordagem sobre a emergência do Constitucionalismo Moderno, Constitucionalização e simbologia das Revoluções Liberais-Burguesas utilizando técnica de pesquisa bibliográfica e método de abordagem dedutivo. Identificou-se que apesar da importância das Revoluções para reconhecimento de direitos permitiram um processo contínuo de discriminação que se incorporou nos sistemas político-jurídicos.
\end{abstract}

PALAVRAS CHAVE: Constitucionalismo; Constitucionalização; Simbologia; Revolução, Liberal-Burguesa.

\section{MODERN CONSTITUTIONALISM: SYMBOLISM OF THE LIBERAL-BOURGEOIS REVOLUTIONS}

\begin{abstract}
:
Modern Constitutionalism emerged from the 18th century as a political, social and cultural movement after a period of rupture with traditional model of political power. The three great political-social movements, English, American and French, known as Liberal-Bourgeois Revolutions, were responsible for formation of Modern Constitutionalism. The article contemplates an approach on the emergence of Modern Constitutionalism, Constitutionalization and symbology of Liberal-Bourgeois Revolutions using bibliographic research technique and deductive approach method. It was identified that despite the importance of the Revolutions for recognition of rights, they allowed a continuous process of discrimination that was incorporated political-legal systems.
\end{abstract}

KEY WORDS: Constitutionalism; Constitutionalization; Symbology; Revolution; LiberalBurguese.

\section{1- Introdução}

A Constituição de um Estado promove importante papel na sociedade atual estruturando e disciplinando o sistema político e estatal, promovendo limites para a atuação dos poderes, estabelecendo as relações entre o Estado e os cidadãos, reconhecendo

1Mestranda em Direito pela Universidade do Extremo Sul Catarinense - UNESC. Especialista em Direito Público pela FMP- RS. Graduada em Direito pela ULBRA-RS. Advogada e pesquisadora. E-mail: alessandramalheiros@yahoo.com.br 
formalmente os direitos fundamentais da pessoa humana e permitindo a formação e porque não a transformação da realidade social.

Para o Estado a Constituição apresenta papel de fundamental relevância que justifica a propositura da pesquisa sobre a emergência do Constitucionalismo Moderno uma vez que este movimento inaugurou um modelo de Estado que se desenvolveu na trajetória histórica e política e que continua em movimento. Ademais, o conhecimento histórico é que permite ampliar e aprofundar a via do conhecimento.

Através da presente pesquisa pretende-se identificar a simbologia das Revoluções Liberais-Burguesas. Para alcançar o resultado o estudo apresenta como objetivos a analise sobre a emergência do Constitucionalismo Moderno, a Constitucionalização, bem como sobre a simbologia das Revoluções Liberais-Burguesas.

A pesquisa se justifica em razão dos impactos da trajetória histórica, política e jurídica acarretados pela emergência do Constitucionalismo Moderno bem como da Constitucionalização que se constituem em importantes observatórios para permitir uma identificação crítica a respeito da simbologia das Revoluções Liberais-Burguesas.

Com base na técnica de pesquisa bibliográfica e na utilização do método de abordagem dedutivo pretende-se extrair conhecimento sobre o conteúdo geral a respeito da emergência do Constitucionalismo Moderno, da Constitucionalização e a respeito das Revoluções Liberais-Burguesas para permitir a conclusão sobre a simbologia destas Revoluções.

\section{2- A emergência do Constitucionalismo Moderno}

O movimento constitucional que produz constituição com as concepções modernas tem origens localizadas em "horizontes temporais" distintos e em momentos históricos e geográficos diferenciados a ponto de se afirmar que não há um constitucionalismo mas vários constitucionalismos como o inglês, o americano, o francês. Para Canotilho seriam vários movimentos constitucionais "com corações nacionais" mas com pontos de aproximação que permitem uma organização histórico-cultural (CANOTILHO, 2002. p.51). Nos dizeres de Canotilho:

Constitucionalismo é a teoria (ou ideologia) que ergue o princípio do governo limitado indispensável à garantia dos direitos em dimensão estruturante da organização político-social de uma comunidade. Neste sentido, o constitucionalismo moderno representará uma técnica específica de limitação de poder com fins garantísticos. $\mathrm{O}$ conceito de constitucionalismo transporta, assim um claro juízo de 
valor. É no fundo, uma teoria normativa da política, tal como a teoria da democracia ou teoria do liberalismo. (CANOTILHO, 2002. p.51)

Dentro porém de outra concepção histórico-descritiva designa-se como Constitucionalismo Moderno a partir do século XVIII o movimento político, social e cultural que questiona o modelo tradicional de domínio político nos planos político, filosófico e jurídico que origina uma nova forma de ordem e fundamento para o poder político (CANOTILHO, 2002. p.52). Acentua Canotilho que:

Este constitucionalismo, como o próprio nome indica, pretende opor-se ao chamado constitucionalismo antigo, isto é, o conjunto de princípios escritos ou consuetudinários alicerçadores da existência de direitos estamentais perante o monarca e simultaneamente limitadores do seu poder. Estes princípios ter-se-iam sedimentado num tempo longo - desde os fins da idade média até o século XVIII. (CANOTILHO, 2002. p.52)

Conhecer a história é indispensável para o "saber constitucional”, não sendo portanto possível compreender o constitucionalismo sem conhecer a história das revoluções americana e francesa e o enquadramento da cena política inglesa dos “João sem Terra”. (CANOTILHO, 2002).

Por esta razão necessário torna-se abordar as circunstâncias históricas em que se desenvolve o Estado Moderno e depois daquele que propicia o constitucionalismo moderno.

Nesse contexto acentua-se que o Estado Moderno surge a partir da crise do feudalismo 2 momento que representa o auge do poder do Estado quando há o reconhecimento e a justificativa do poder. O reinado unifica o reino e passa a ter força para expulsar os Impérios. Passa a existir um poder organizado, centralizado, exercido nos limites de um território, onde se aplica o direito produzido por este Estado e vai haver a necessidade da criação de um Estado nacional3 e logo de um povo nacional. Surge, então o absolutismo

2 “Tratava-se de uma sociedade estamental, fundada na posse da terra e na produção econômica agrária, profundamente marcada por relações de servidão (laços de subordinação pessoal entre suserania e vassalagem) e por uma hierarquia de privilégios. Os limites da política e juridicidade se definem tendo por base a propriedade da terra, a forte relação de dependência e os estreitos vínculos comunitários. Já no que tange à organização do poder senhoral, o sistema feudal compreende tanto uma descentralização administrativa quanto uma fragmentação e pluralismo de centro de decisões. O pluralismo político medieval se dá mediante a infinita multiplicidade de centros internos de poder político, distribuídos a nobres, bispos, universidades, reinos, entidades intermediárias, estamentos e corporações de ofício. Distintamente da sociedade moderna, centrada no interesse do espaço privado e na ética da racionalidade liberal-individualista, o pensamento ideológico medieval é calcado na concepção "corporativa" da vida social, valorizando os fenômenos coletivos e os múltiplos corpos sociais, cada qual com sua autonomia interna para as funções políticas e jurídicas, mas dispostos a colaborar com o conjunto e dele participar solidariamente." (Wolkmer, 2015 p. 25).

3 O povo nacional é uma invenção. O Rei e a Rainha pertencem a uma etnia diferente e o povo precisa de algo que os una ao rei (identificação entre os grupos para se identificarem com o rei). No século XV e XVI começam os Estados Nacionais e a identidade nacional vai ser um fator muito importante para manter a estrutura e o poder do Estado Moderno e isso gera muita violência porque o Estado Moderno é unificador e rejeita e nega 
apoiado pela burguesia (em ascensão decorrente do modo de produção capitalista) que passa a apoiar o rei para posteriormente almejar o poder. (MAGALHÃES, 2011)

O Estado Moderno, em uma primeira versão absolutista, é originário do desfazimento da forma de Estado Medieval e surge sem Constituição (em visão strictu sensu). No entanto, é exatamente o absolutismo que vai permitir a existência de mecanismo de limitação do poder, o que vai ocorrer na Inglaterra, século XVII, na França, fins do século XVIII e com a Declaração de Independência das colônias americanas que origina a Constituição de 1787 (STRECK, 2018).

Nas palavras de Wolkmer (2015, p. 36):

\begin{abstract}
Atinente ao amplo processo de racionalização ético-filosófico e técnico-produtivo que contextualiza a modernidade capitalista e burguesa, emerge, concomitantemente, uma cultura liberal-individualista4. [...] Eram necessárias novas convicções que legitimassem as novas potencialidades de riqueza que os homens haviam descoberto, pouco a pouco, nas eras precedentes. [...] e, em função disso, desenvolveu-se uma nova filosofia racional do novo mundo que assim nascera.
\end{abstract}

O Estado era o "fantasma" do indivíduo representando a restrição da liberdade primitiva (BONAVIDES, 2001, p. 40)5. "Foi assim - da oposição histórica e secular, na idade Moderna entre a liberdade do indivíduo e o absolutismo do monarca - que nasceu a primeira noção do Estado de Direito[...]” (BONAVIDES, 2001, p. 41).

Três grandes movimentos político-sociais permitiram a transposição dos ideais iluministas daquele contexto para o plano prático: a Revolução Inglesa que se expressou no Bill of Rights, de 1689 com a influência de Locke; a Revolução Americana com princípios que se tornaram expressos na Declaração de Independência das treze colônias americanas em

a diferença. A Uniformização é necessária dentro da perspectiva do Estado Moderno para que haja um único poder central. Tratava-se de um projeto narcisista, exacerbação dos nacionalistas (melhor que os outros; Nós x eles). Há um grupo hegemônico que se impõe sobre os demais e, neste contexto cria-se o Estado, o exército nacional, a moeda, os bancos nacionais, a polícia nacional para manter o poder do rei e reprimir os pobres. (Magalhães, 2011)

4 “[...] o Liberalismo surgiu como uma nova visão do mundo, constituída pelos valores, crenças e interesses de uma classe social burguesa na sua luta histórica contra a dominação do feudalismo aristocráticofundiário, entre os séculos XVII e XVIII, no continente europeu. Assim, o Liberalismo torna-se a expressão de uma ética individualista voltada basicamente para a noção de liberdade total que está presente em todos os aspectos da realidade, desde o filósofo até o social, o econômico, o político, o religioso, etc. Em seus princípios, o Liberalismo se constitui na bandeira revolucionária que a burguesia capitalista (apoiada pelos camponeses e pelas camadas sociais exploradas) utiliza contra o Antigo Regime Absolutista. Acontece que, no início, o Liberalismo assumiu uma forma revolucionária, marcada pela "liberdade, igualdade e fraternidade", que favorecia tantos os interesses individuais da burguesia enriquecida quanto os de seus aliados economicamente menos favorecidos. Mais tarde, contudo quando o Capitalismo começa a passar à fase industrial, a burguesia (a elite burguesa), assumindo o poder político e consolidando seu controle econômico, começa a "aplicar na prática somente os aspectos da teoria liberal" que mais lhe interessam, denegando a distribuição social da riqueza e excluindo o povo do acesso ao governo."(WOLKMER, 2015, p. 37)

5 Doutrina do Liberalismo. 
1776; e a Revolução Francesa, que universalizou os seus princípios expressos na Declaração do Homem e do Cidadão de 1789 sob a influência de Rosseau (DALLARI, 2011, p. 147).

Pois bem os ideais iluministas que agitavam os burgueses e intelectuais eram motivados pelas transformações que ocorriam na Europa com ênfase nos campos religioso e comercial.

Então da contraposição entre liberdade do indivíduo e o absolutismo do monarca, que configura a oposição secular e histórica da Idade Moderna, nasce a concepção de Estado de Direito concebido da evolução teórica e “decantação conceitual” (BONAVIDES, 2001).

Os movimentos inglês, francês e americano representaram portanto, um grande momento de ruptura.

A burguesia até então classe dominada passa à classe dominante com suporte nos princípios filosóficos de sua revolta social que são generalizados como ideias comuns de todo o corpo social. Após a conquista do controle político já não há mais o interesse na manutenção do ideário dito "universal" e então mais tarde no século XX quando as estruturas de "Estado Jurídico Puro" se tornam ilógicos e abstratos diante das realidades sociais há o impulso da primeira fase do constitucionalismo burguês. "Da liberdade do Homem perante o Estado, a saber, da idade do liberalismo, avança-se para a ideia mais democrática da participação total e indiscriminada desse mesmo Homem na formação da vontade estatal." (BONAVIDES, 2001, p. 42-43).

Fundado nesse contexto Magalhães sustenta (2018, p. 3) que "O Estado moderno foi a grande criação da modernidade, somada mais tarde, no século XIX, com a afirmação do Estado Constitucional.”.

Tomando-se em conta o constitucionalismo moderno como sucessor da ruptura social e política acarretada pelas revoluções ditas burguesas Canotilho (2002, p. 52) explica:

\begin{abstract}
Numa outra acepção - histórico-descritiva - fala-se em constitucionalismo moderno para designar o movimento político, social e cultural que, sobretudo a partir de meados do século XVIII, questiona nos planos político, filosófico e jurídico os esquemas tradicionais de domínio político, sugerindo, ao mesmo tempo, a invenção de uma nova forma de ordenação e fundamentação de poder político. Este constitucionalismo, como o próprio nome indica, pretende opor-se ao chamado constitucionalismo antigo6, isto é, um conjunto de princípios escritos ou consuetudinários alicerçados da existência de direitos estamentais perante o monarca e simultaneamente limitadores de seu poder. Esses princípios ter-se-iam sedimentado num tempo longo - desde os fins da idade média até o século XVIII.
\end{abstract}

\footnotetext{
6 "Por vezes, designa-se constitucionalismo antigo todo o esquema de organização político-jurídica que precedeu o constitucionalismo moderno. Caberiam neste conceito amplo o "constitucionalismo grego" e o "constitucionalismo romano" (Dogliani apud Canotilho 2002 p. 52)
} 
Desde as origens o constitucionalismo é uma corrente de pensamento voltada a concretização de finalidades políticas consistente na limitação dos poderes públicos e consolidação das autonomias através das normas. O Constitucionalismo nasce e se consolida com o Estado moderno europeu desenvolvendo-se neste contexto o princípio da soberania e desenvolvendo-se também o processo de concentração de poder público sobre um território (FIORAVANTI, 2009).

A partir das constituições escritas elaboradas pelos Estados independentes norteamericanos que culminaram na Constituição Federal de 1787 a era do constitucionalismo moderno inicia a escalada com a promulgação da Declaração dos Direitos do Homem e do Cidadão na França em 1789 que incorporava em seu artigo 16 o novo conceito de constituição estipulando que o Estado que não garantisse a separação dos poderes e não assegurasse direitos individuais não teria uma constituição (SARLET; MARINONI E MITIDIERO, 2015, p. 49)

$\mathrm{Na}$ França a divergência cultural decorrente de fatores geográficos e históricos nas diversas partes dos Estados francês era geradora de diversidade nos costumes e de consequente diversidade nas regras jurídicas costumeiras o que não convinha para a ideia de afirmação de um só povo e afirmação de unidade de Estado que estava consolidado politicamente. Daí a ideia de reunir regras fundamentais em um corpo homogêneo comum a todo o povo. Então com a conjugação de interesses, convicções, proposições teóricas e objetivos porém com dificuldades de natureza prática afirma-se esta ideia de necessidade de um corpo unificado de regras jurídicas básicas, um código com elaboração prevista na primeira Constituição francesa de 1791 (DALLARI, 2013).

Então "O velho Estado liberal das épocas clássicas" após expirar a missão revolucionária e sedimentar a racionalidade, incorpora às instituições estatais consolidando a separação dos poderes como garantia constitucional da liberdade e como a herança mais sólida almejada e conquistada (BONAVIDES, 2001, p. 14).

\section{A Constitucionalização}

Com a intenção de abordar a constitucionalização como fenômeno que estabelece determinada ordem jurídica e política a partir de uma estrutura normativa representativa do 
contexto social e político em que se insere, vê-se como fundamental trabalhar o conceito de Constituição.

O conceito de Constituição admite variações históricas. Acerca de um conceito de Constituição, Neves (2011 p. 57) analisa:

A discussão sobre o conceito de Constituição remonta a Aristóteles. Nele, a
Constituição (politeía) era concebida, em um sentido muito abrangente, como a
ordem da pólis: "... Constituição é a ordem (táxis) dos Estados em relação aos
cargos governamentais (iarkhé), como eles são de distribuir-se, e à determinação do
poder governamental supremo no Estado, como também do fim (télos) da respectiva
comunidade (koinonía)". Conforme esse conceito de organização da pólis, o qual
incluía elementos estruturais e teleológicos, Constituição e Estado podiam ser
equiparados. Sem desconhecer que somente a partir dos fins do século XVIII
tornou-se corrente, nas traduções de Aristóteles, verter "politeía" em "Constituição",
tendo prevalecido anteriormente a tradução pela palavra inglesa "government", cabe
assinalar que o conceito aristotélico desempenha um importante papel até o início
dos tempos modernos. Porém, na transição para a sociedade moderna, abre-se uma
nova constelação semântica, no âmbito da qual a Constituição é conceituada como
carta de liberdade ou pacto de poder. Em contraposição ao caráter apenas
"modificador do poder", "casuístico" e "particular" dos pactos de poder, surge, no
quadro das revoluções burguesas dos fins do século XVIII, o constitucionalismo
moderno, cuja semântica aponta tanto para o sentido normativo quanto para a função
"constituinte de poder", "abrangente" e "universal" da Constituiçãa.

Bercovici (2013 p. 14) por sua vez a partir de uma visão crítica analisa o significado da constituição sob o viés de uma manifestação política:

A constituição é a declaração da vontade política de um povo, é um ato de soberania,
um ato constituinte. Fruto do conflito de forças político-sociais, cuja resolução vem
pela superação, não pelo escamoteamento, a constituição precisa ser desmistificada,
sob o risco de se tornar um instrumento de dominação ideológica.
$[\ldots]$ Os autores que defendem uma concepção exclusivamente normativa de
constituição entendem a constituição apenas como a norma superior do
ordenamento, que configura, ordena e limita os poderes estatais. [...] Com a
tendência dos constitucionalistas se limitarem à esfera exclusivamente jurídica,
acabam perdendo a visão da vida constitucional de um país, desprezando a esfera
política e a realidade social.

Em análise a respeito de política e direito e o emprego do termo "constitucionalização" é possível identificar que nem toda a ordem jurídico-política estatalmente organizada desenvolveu um sistema constitucional. Nesta concepção o termo Constituição refere-se ao sentido moderno concebida como "uma limitação jurídica ao governo", "a antítese do regime arbitrário" (constitucionalismo) e neste contexto não necessariamente estar-se-ia falando de “ "declaração" de valores político-jurídicos preexistentes, inerentes à pessoa humana, ou como produto da evolução da consciência moral no sentido de uma moral pós-convencional ou universal". Na concepção moderna pode-se dizer que a Constituição seria fator e produto da diferenciação das funções entre direito e política como "subsistemas da sociedade", 
mecanismo de interpenetração da política e do direito (NEVES, 2011 p. 65-67)

Ressalta-se que no segundo pós-guerra o papel da Constituição e suas relações com a política voltou ao palco das discussões. As Constituições do século XX, em especial as do pós $2^{\mathrm{a}}$ Segunda Guerra Mundial são constituições políticas e não apenas estatais. O debate sobre o papel da Constituição e suas relações com a política foi retomado neste momento histórico “Assumem conteúdo político, ou seja, englobam os princípios de legitimação do poder, não apenas sua organização.” (BERCOVICI, 2004, p. 9). Ainda nas expressivas palavras de Bercovici (2004 p.9):

O campo constitucional é ampliado para abranger toda a sociedade, não só o Estado.

A Constituição, nas palavras de Konrad Hesse, também é a "ordem jurídica fundamental da comunidade", ou seja, ela é Constituição do Estado e da sociedade. A política se manifesta não apenas na instauração da Constituição (o poder constituinte originário), mas também nos momentos seguintes, de efetivação da ordem constitucional por meio de uma política constitucional. O grande protagonista das concepções, consubstanciadas com a Teoria da Constituição, segundo Fioravanti, é o partido político, intermediário entre o Estado e a sociedade, englobados agora pela Constituição. [...] A idéia da Constituição como totalidade, ressaltando-se o seu caráter dinâmico (não garante apenas uma ordem estática), "politiza" o conceito de Constituição, que não se limita mais a sua normatividade.

Portanto, "Estado e Constituição formam uma unidade no Estado Constitucional. Mas as relações recíprocas entre Estado e Constituição devem implicar a não primazia do Estado.” (BERCOVICI, 2004 p. 23).

Segundo Hans Peter Schneider apresentado por Bercovici (2004 p. 9-10) a Constituição teria três dimensões: “a dimensão democrática (formação da unidade política), a dimensão liberal (coordenação e limitação do poder estatal) e a dimensão social (configuração social das condições de vida).". Tais funções estariam conectadas e mutuamente se condicionariam, não poderiam ser entendidas de forma isolada e não poderiam ser “absolutizadas". Sendo assim, a Constituição não se limitaria a regular procedimentos e decisões governamentais tão pouco teria a finalidade de criar elo de ligação a qualquer conflito, só podendo ser compreendida em sua totalidade.

\section{4- Simbologia atribuída pelas revoluções liberais}

Antes mesmo que ocorressem as revoluções liberais no período em que alguns autores constitucionalistas identificam como o do "Constitucionalismo Antigo" destacava-se o anseio pela limitação do poder com o consequente reconhecimento de direitos. Por esta razão, alguns 
acontecimentos ficaram marcados pelo reconhecimento formal de alguns direitos sempre em contextos de disputa de poder econômico e político. Na Inglaterra destaca-se a Magna Charta Libertatum, em 1215, documento imposto ao Rei João Sem Terra, a Petition of Rights, a Habeas Corpus Act.

Coma ascensão da burguesia, classe que havia ganhado expressão econômica, impulsionada pelas ideias iluministas e liberais havia estímulo muito grande para que obtivessem também regras que permitissem a salvaguarda dos seus interesses enquanto classe o que acaba sendo o principal vetor dos movimentos revolucionários.

O absolutismo representava reiterada prática de abusos contra a liberdade, o patrimônio a integridade física e a dignidade de pessoas que não detinham poder político. As pessoas mais pobres eram vítimas mas também o eram os burgueses que se viam impotentes contra as arbitrariedades (havia desrespeito às contratualidades e violência contra a pessoa e patrimônio) e, portanto, havia um anseio pela segurança das relações econômico-financeiras e para isso necessários que se estabelecesse regras claras e duráveis que não se sujeitassem aos caprichos dos governantes e tal necessidade foi impulsionadora do desenvolvimento da ideia sobre Constituição como estatuto político-jurídico fundamental e como um limitador das ações políticas não havendo ainda neste contexto a concepção de Constituição como base jurídica das relações sociais (DALLARI, 2013)

O Absolutismo que se desenvolvia de forma diferente na França e na Inglaterra vai dar ensejo ao desenvolvimento da racionalidade e do individualismo que marca o momento de ruptura indicado como o período das revoluções. No entanto, o momento de ruptura se apresenta com as particularidades de cada história local. Assim na Inglaterra, nos Estados Unidos e na França o quadro de ruptura vai dar abertura para o desenvolvimento da Constitucionalização que também irá apresentar simbologia diferente em cada um dos casos.

A Revolução Francesa7, última das revoluções liberais, procurou identificar uma nova ordem em relação aos direitos considerados naturais dos indivíduos enquanto integrantes de uma ordem jurídica estamental, perseguiu a defesa para além dos direitos de liberdade e propriedade em face do poder político vigente pretendendo a ruptura com o antigo regime

7 “As exigências do ideário liberal-burguês foram delineadas na Declaração de Direitos, documento jurídico que representava ao mesmo tempo um manifesto contra a sociedade hierárquica e os privilégios da nobreza, muito embora estivesse longe de poder ser considerado um libelo em prol de uma sociedade democrática e igualitária. O ideal era a formação de um Estado secular, que assegurasse as liberdades civis e as garantias para a empresa privada, e de um governo de contribuintes e proprietários, elevando-se a propriedade privada condição de direito natural, sagrado, inalienável e inviolável.” (SARLET; MARINONI E MITIDIERO, 2015,p. 49). 
para estabelecer um novo regime que significava uma nova ordem social e em segundo momento a fundação e legitimação de um novo poder político (CANOTILHO, 2002).

É a Revolução Francesa que inaugura uma nova fase do Estado Moderno significando o triunfo da soberania popular onde a nascente burguesia que havia delegado poder político ao soberano passa a não se contentar apenas com o poder econômico e na pretensão de tomar para si o poder político apoia-se no descontentamento das classes sociais com o comportamento do poder monárquico absoluto para alcançar o objetivo pretendido (STRECK, 2004).

No contexto havia um forte patrimonialismo que centralizava a ideia de propriedade individual como um valor preponderante e condicionante da vida social e que era o suporte das ideias do individualismo, do privatismo e do legalismo. Como os burgueses não eram herdeiros de títulos de nobreza e portanto não detinham tradição familiar de superioridade social valorizavam àquilo que poderia lhe conferir um parâmetro de superioridade e ascensão social que legitimasse a participação no governo e na sociedade, ou seja, o seu patrimônio material. Motivo pelo qual o desenvolvimento teórico civil8 vai ganhar mais expressão do que o Constitucionalismo na França no pós-revolução9 (DALLARI, 2013).

Já na Inglaterra a Revolução Gloriosa marca a história constitucional inglesa tendo a Declaração de Direitos de 1689 como um importante documento escrito que demarca e limita os poderes da legislatura e do monarca (STRECK, 2004). Nas palavras de Paixão e Bigliazzi conforme apresenta Streck (2004, p. 44) a Declaração de Direitos representou:

Tal evolução, por sua vez, naquilo que legou ao mundo o modelo parlamentar e um primeiro sistema de liberdades civis e políticas, pode ser considerada como a grande contribuição inglesa ao constitucionalismo e para a história das instituições políticas $[\ldots]$.

Ressalta-se, no entanto, que a Inglaterra possuía elementos de um moderno Estado constitucional mesmo antes da declaração da independência dos Estados Unidos da América e

$8 \quad[\ldots]$ o desenvolvimento teórico do direito civil na França foi motivado, em grande parte, pela ideia, exposta por Montesquieu, de que o governo da lei é melhor que o governo dos homens. Essa crença levou ao culto do legalismo, que produziu o positivismo jurídico consagrando uma concepção individualista dos direitos e o mais exacerbado privatismo (DALLARI, 2013, p. 102).

9 Na França tendo como incentivador Napoleão Bonaparte "Aprovado em Assembleia em 1804, o Código Civil passa a ser visto e utilizado como a expressão máxima do Direito, a lei por excelência, gozando da presunção de legitimidade e justiça.”(DALLARI, 2013, p. 107). A teoria jurídica civilista na França acaba qualificando o "legicentrismo" e o "positivismo jurídico" consagrando o Código Civil como lei fundamental o que acarreta o retardamento em duzentos anos do desenvolvimento da natureza jurídica da Constituição que foi utilizada na França por muito tempo como um instrumento essencialmente político que definia uma forma de governo oposta ao absolutismo, objetivos políticos de um povo e sintetizava valores éticos. (DALLARI, 2013). 
das constituições americana, francesa e polonesa10. Já vigorava na Inglaterra um sistema de limitação do poder, o devido processo legislativo formal, um regime parlamentar com representação popular e era existente um conjunto de garantias e liberdade civis garantido por documentos jurídicos "quase-constitucionais" mesmo que com concepção distinta da atual concepção de direitos fundamentais. Do ponto de vista econômico e político a Inglaterra era a mais liberal do antigo regime. Burguesia e nobreza tinham representação no parlamento. $\mathrm{O}$ modelo inglês ainda hoje não possui constituição escrita e não se baseia em poder constituinte e poder constituído, não contempla o princípio da supremacia da constituição pois adota a supremacia parlamentar, sendo um modelo em permanente reconstrução distinto do modelo constitucional escrito mas ainda sim contempla elementos importantes do Estado constitucional (SARLET; MARINONI E MITIDIERO, 2015).

De acordo com Dallari (2013) a Inglaterra do Século XVII vai se caracterizar por refletir os anseios de novas formas de organização política e social o que favorece a definição de valores humanistas inerentes à condição humana. Estes valores não estavam exclusivamente ligados à correção de situações particularizadas de injustiça identificada por privilégios. Havia um sistema de dominação exercido por grupos sociais: a nobreza que impunha regras de convivência e comportamento e havia também grupos sociais que representavam dominação e liderança (como as corporações que regulavam o comércio e os ofícios garantindo situação privilegiada aos que dominavam tais corporações).

Então a Inglaterra do século XVII e XVIII vai se caracterizar por um sistema em que os indivíduos se identificam pela pertinência a um grupo social até mesmo religioso. Surgindo sobre essa forma de dominação "as aspirações políticas do individualismo" independente do grupo a que possa pertencer, passa-se a falar do indivíduo e dos direitos que este indivíduo possa ter. Ao mesmo tempo a razão como nova concepção teórica passa a se sobrepor sobre a providência divina (racionalidade); razão que se funda na natureza de onde emanam as regras de convivência que são naturais e não impostas pela vontade de alguém (DALLARI, 2013).

Uma sucessão de pensadores políticos ingleses irão basear suas teorias no direito natural à liberdade como sustentação da convivência humana mas irão se concentrar em princípios econômicos e não políticos caracterizando o liberalismo liberal-burguês. Jeremy Bentham e James Mill desenvolvem na Inglaterra o utilitarismo como linha de pensamento onde a política vai se justificar na utilidade de favorecer a felicidade dos homens. E, neste

10 Todas do final do século XVIII. 
sentido as ações humanas seriam conduzidas para busca da felicidade individual e prazer, concluindo que o melhor governo é o que permite aos indivíduos serem bem-sucedidos limitando-se o Estado a assegurar a ordem criando condições para o sucesso econômico que levará à felicidade coletiva através do impulso individual (DALLARI, 2013).

No que se refere a experiência constitucional dos Estados Unidos da América em 04 de julho de 1776 foi a data da assinatura da Declaração da Independência das antigas colônias da Inglaterra na América do Norte o que significou a constituição de Estados independentes e soberanos. E, em 1781 os Estados ratificaram os termos da Confederação ${ }^{11}$. Visando formar uma unidade fortalecida convocou-se a Convenção de Viena que aprova em $1787^{12}$ a primeira, na concepção moderna do termo, Constituição jurídica escrita dos Estados Unidos da América enquanto nação independente e soberana e, através deste pacto político fica criada a primeira República Federativa e Presidencialista "no âmbito a evolução político-institucional da humanidade"13 (SARLET; MARINONI E MITIDIERO, 2015). De acordo com Sarlet (in SARLET; MARINONI E MITIDIERO, 2015, p. 47):

\begin{abstract}
Importa notar, todavia que, embora o título de primeira constituição moderna seja atribuído ao documento elaborado em 1787, já desde a declaração de Independência, em 1776, quando as antigas colônias constituíram Estados independentes, a noção de constituição em sentido moderno e, com ela, a própria noção de um poder constituinte já se faziam presentes, precisamente pelo fato de que os novos Estados originários das colônias experimentaram um processo de formação constitucional que apresentava as características que depois vieram a se consolidar quando da aprovação da Constituição em 1787. [...] Tudo isso revela que a construção da Constituição americana se deu mediante um processo que vai pelo menos de 1776 (Declaração de Independência) até 1791 (incorporação de uma declaração de direitos ao texto da Constituição de 1787). Tal processo veio a ser consolidado posteriormente mediante entre outros aspectos, a consolidação da noção de supremacia da Constituição[,...].
\end{abstract}

Vê-se que o constitucionalismo apresenta significado diferente nos Estados Unidos da América em comparação ao que seu deu na França. Havia a preocupação em evitar a herança inglesa do absolutismo e a preocupação de estabelecer uma estrutura normativa para a consolidação e fortalecimento do Estado pela união indissolúvel das antigas colônias através da criação da Federação.

11 Em 1781 os Estados soberanos ratificaram os Articles of Confederation estabelecendo uma confederação de treze Estados soberanos em razão na necessidade de fortalecer a união com intenção de enfrentar o inimigo comum, Inglaterra porque a guerra interna ainda não estava vencida.

12 O texto só entrou em vigor em julho de 1788 após a ratificação por todos os Estados que compunham a Confederação que renunciam a soberania. (SARLET; MARINONI E MITIDIERO, 2015, p. 47)

13 De acordo com Paixão e Bigliazzi nos dizeres de Sarlet, Marinoni e Mitidiero (2015, p. 46-47) “[ ...] a Constituição de 1787 não foi resultado de uma decisão prévia e planejada, mas sim, a forma encontrada pelos integrantes da Convenção da Filadélfia para resolver um problema concreto e imediato, qual seja o da estruturação e organização interna de poder.". 
$\mathrm{Na}$ Constituição Americana foi estruturada a separação dos poderes, com igual submissão a eles, houve a preocupação de manutenção da unidade nacional e com assegurar a liberdade individual14 contra excessos do poder público. As disposições constitucionais americanas acarretaram o desenvolvimento de uma teoria constitucional nos Estados Unidos no início do século XIX que se dá pela atuação de juristas através de solução de dúvidas e controvérsias havendo a criação da concepção de Supremacia da Constituição. (DALLARI, 2013).

As Revoluções liberais tiveram uma grande simbologia com o legado da experiência constitucional deixado representando o início do Constitucionalismo Moderno e seu desenvolvimento no continente europeu que evolui para a ampliação do constitucionalismo pelo mundo ocidental e nos dizeres de Sarlet (in SARLET; MARINONI E MITIDIERO, 2015, p. 51) "rumo ao modelo de Estado Constitucional como paradigma universal".

$\mathrm{Na}$ medida em que a Assembleia Nacional Constituinte na França significou ruptura com o passado porque não apenas fundava um Estado mas um novo modelo social e uma nova ordem estatal afetando as estruturas da sociedade com a extinção do direito feudal, os privilégios da aristocracia e a limitação do poder do Estado a experiência norte-americana consolida o ideário de supremacia da constituição e a noção de soberania popular como fundamento do Poder do Estado, a garantia dos direitos fundamentais (incorporada com as dez emendas de 1791 "Bill of Rights") como salvaguarda de liberdades e igualdade das pessoas diante do poder estatal; a separação dos poderes limitados e controlados entre si, a ideia de Federação (criação de um Estado comum) com repartição de tarefas estatais entre União e Estados federados (SARLET; MARINONI E MITIDIERO, 2015).

Ressalta-se também a experiência inglesa que através de sua tradição constitucional tem significado relevante para afirmação do cenário do jurídico-constitucional e político do final do século XIX (SARLET; MARINONI E MITIDIERO, 2015).

Por outro lado, na concepção de Dallari (2013) não seria possível afirmar que o Constitucionalismo tenha nascido das lutas contra o absolutismo mas que fora de forma intensa estimulado como forma de reação e resposta às arbitrariedades e violência dos regimes absolutistas. Reforça o emitente autor que a realidade do absolutismo inglês e francês (que

14 Porém, observa-se que esta garantia constitucional de liberdade como direito fundamental do indivíduo só tinha significado quando falava-se em proteção de interferências do Poder Público na vida privada porque em outras circunstâncias era totalmente esquecida o que pode ser exemplificado com a manutenção da escravidão que só fora abolida em 1865 com a guerra entre o Norte abolicionista e o Sul escravista (DALLARI, 2013). 
tinham características diversas) dirigiu a evolução do constitucionalismo resultando em modelos diferentes de Constituição.

Os pensamentos teóricos liberalistas serão influenciadores da prática política e posteriormente irão influenciar no desenvolvimento do Constitucionalismo liberal-burguês.

\section{5- Conclusão}

$\mathrm{Na}$ proposição de analisar a emergência do Constitucionalismo Moderno, a Constitucionalização, bem como a simbologia das Revoluções Liberais-Burguesas A FIM DE QUE SE possibilitasse uma concepção Crítica sobre o tema apresentam-se as considerações finais advindas do presente estudo.

O Constitucionalismo Moderno é resultado de um processo de ruptura ocorrido no final do século XVII e no século XVIII representado pelas Revoluções Liberais-Burguesas na Inglaterra, nos Estados Unidos da América e na França. No contexto que antecedia as Revoluções vigorava como expressão do Poder o Absolutismo onde o poder político era desempenhado pelos nobres com a participação da Igreja e no caso Inglês com a participação dos representantes das corporações de oficios. A burguesia em ascensão econômica não detinha o poder político e influenciada pelos ideais iluministas e liberais se contrapõe ao Regime Absolutista para garantir participação política com o reconhecimento de direitos individuais, o reconhecimento da liberdade como direito natural voltado às concepções econômicas e o reconhecimento de independência e limitação do poder.

Este contexto vai permitir a formação de um movimento constitucionalizador com diferentes aspectos na Inglaterra, nos Estados Unidos da América e na França. E, cada um deles com suas peculiaridades vai influenciar o início do Constitucionalismo em diversos Estados o que não vai significar inicialmente a Constitucionalização.

A Constitucionalização pode ser identificada como fenômeno que estabelece uma determinada ordem jurídica e política a partir de uma estrutura normativa representativa do contexto social e político em que se insere. Por esta razão, alguns Estados adotaram o Constitucionalismo mas inicialmente não houve uma Constitucionalização. A própria França em sua primeira Constituição de 1791 trazia elementos muito mais de significados políticos do que propriamente jurídicos porque não contemplava as definições políticas e jurídicas sendo que estas últimas acabaram sendo definidas pela legislação civilista francesa. 
Assim, identifica-se que não há uma homogeneidade na trajetória Inglesa, Americana e Francesa uma vez que o Absolutismo francês que originou a Revolução detinha um caráter diferente do Inglês onde já havia uma certa divisão de exercício do poder, com participação política de determinadas classes, como um modelo desenvolvido ao longo da história e decorrente do particular desenvolvimento da sucessão monárquica. Os Estados Unidos por sua vez tem o movimento revolucionário caracterizado pela independência das treze colônias da Inglaterra com a assinatura do documento de Declaração que institui a Confederação e onze anos depois tem a sua primeira Constituição definidora de uma estrutura federalista com o fortalecimento da unificação, a consolidação da separação dos poderes e que acaba por permitir a criação do instituto do controle de constitucionalidade.

Desta forma, identifica-se que as Revoluções Liberais-Burguesas significaram além da ruptura a permissão para que se inaugurasse um novo modelo de Estado que vai legar o início da trajetória para a construção do Estado Constitucional.

No entanto, é necessário que se identifique a existência da herança que implicitamente se originou das Revoluções uma vez que na França o documento que representava o movimento revolucionário, a Declaração dos Direitos do Homem e do Cidadão, na própria titulação já mantém fator discriminatório e de elitização porque traduz a ideia de conferir direitos àquele dito "homem cidadão" e não à todas as pessoas francesas que foram incitadas a tomada do poder pela luta armada durante todo o longo período em que a Revolução se deu em nome do direito de liberdade. A burguesia que incitava a revolução sob a bandeira da liberdade preocupava-se em resguardar o seu poder econômico, protegê-lo e ditar os rumos de sua atividade sem interferências. Na Inglaterra por sua vez, o ideário da racionalidade iluminista e da liberdade individual como direito natural converteu-se na ideia de liberdade econômica que permitisse o alcance da felicidade com a mínima interferência do Estado, ou seja, fomento à liberdade econômica. E nos Estados Unidos as disposições que reconheceram o direito de liberdade os relegava àqueles que eram considerados dignos dela por poderio econômico, por gênero, por sua raça, ou seja, a Constituição limitava a interferência estatal e conferia liberdade para alguns que eram "dignos" conforme estrutura econômica elitista então estabelecida.

É possível identificarmos portanto que as Revoluções Liberais-Burguesas que significaram e impulsionaram o início do Constitucionalismo Moderno através da modificação das estruturas de poder, e foram campo propulsor para o desenvolvimento de 
diversos sistemas jurídicos, acobertaram discriminações que foram se incorporando nos sistemas jurídicos e que repercutem ainda na atualidade.

\section{6- REFERÊNCIAS:}

BERCOVICI, Gilberto. Constituição e política: uma relação difícil. Lua Nova, São Paulo , n. 61, p. 5-24, 2004. Disponível em:

http://www.scielo.br/scielo.php?script=sci_arttext\&pid=S0102-

$64452004000100002 \& \operatorname{lng}=\mathrm{en} \& \mathrm{nrm}=$ iso. Acesso em 10 Nov. 2019.

http://dx.doi.org/10.1590/S0102-64452004000100002.

BERCOVICI, Gilberto. Soberania e Constituição: Para Uma Crítica do Constitucionalismo. 2. ed. São Paulo: Quartier Latin, 2013.

BONAVIDES, Paulo. Do Estado Liberal ao Estado Social. 7. ed. São Paulo: Malheiros Editores, 2001.

CANOTILHO, J.J.Gomes. Direito Constitucional e Teoria da Constituição. 6. ed. Coimbra - Portugal: Livraria Almedina, 2002.

DALLARI, Dalmo de Abreu. Elementos de Teoria Geral do Estado. 30. ed. São Paulo: Saraiva, 2011.

DALLARI, Dalmo de Abreu. A Constituição na vida dos povos. 2. ed. São Paulo: Saraiva, 2013.

FIORAVANTI, Maurizio. Constitucionalismo. Experiências históricas y tendencias actuales.Tradução de Adela Mora Cañada y Maniel Mrtínez Neira. 2009.

MAGALHÃES, José Luiz Quadros de. Violência e Modernidade: O Dispositivo de Narciso. A superação da modernidade na construção de um novo sistema mundo. Publicado em 12 nov 2011. Acesso em: 12 nov. 2019. Disponível em:

https://joseluizquadrosdemagalhaes.blogspot.com/search?q=estado+moderno

NEVES, Marcelo. A constitucionalização simbólica. $3^{\text {a }}$ ed. São Paulo: Editora WMF Martins Fontes, 2011.

WOLKMER. Antônio Carlos. Pluralismo Jurídico: fundamentos de uma nova cultura do direito. 4. ed. rev. e atual. São Paulo: Saraiva, 2015.

SARLET, Ingo Wolfgang; MARINONI, Luiz Guilherme; Mitidiero, Daniel. Curso de Direito Constitucional. 4. ed. ampl. incluindo novo capítulo sobre direitos fundamentais. São Paulo: Saraiva, 2015.

STRECK, L. L. Jurisdição constitucional e hermenêutica: uma nova crítica do direito. Rio 
de Janeiro: Forense, 2004. 